Wilken Engelbrecht

Univerzita Palackého Olomouc \& Katolicki Uniwersytet Lubelski

https://doi.org/10.18485/bgd_nlistiek_30.2018.ch10

\title{
LJUBAV ZA LJUBAV OF HOE EEN SLOVEEN EEN BELANGRIJKE VERTALER IN HET TSJECHISCH WERD ${ }^{1}$
}

\begin{abstract}
Otto Franjo Babler (1901-1984) was with some 4,000 translations one of the most important literary translators of Czechoslovakia in the $20^{\text {th }}$ century, especially for older poetry. Babler was of mixed German-Slovenian-Czech descent. He was born in Bosnian Zenica, during WW I his widowed mother returned to Bohemia where Babler spent most of his life in Olomouc. Since his youth, he was interested in translation, he started to translate already during his student years. His translations of medieval and renaissance Dutch literature had a certain impact on the reception of Dutch literature in the Czech literary field. In the paper, Babler's life is presented with a focus on his translations from Dutch.
\end{abstract}

Keywords: Otto F. Babler, translation, poetry, Czech, Dutch, Catholic

\section{Voorspel}

Wie ooit door het park onder het gebouw van de neerlandistiek aan de oostkant van de binnenstad van Olomouc heeft gewandeld, kent het tempeltje dat in het park onder het machtige jezuïetenconvict staat. Op de gevel van het tempeltje staat in het Servisch Ljubav za ljubav, liefde voor de liefde, niet geheel correct in hetzelfde opschrift in het Tsjechisch vertaald als Vèrnost za věrnost, trouw voor de trouw. Het 11 meter hoge tempeltje is in 1926 gebouwd als grafmonument voor 1187 Zuidslavische soldaten (merendeels Serviërs) die tijdens Wereldoorlog I als krijgsgevangenen in het militair hospitaal van Olomouc zijn gestorven. De toenmalige Tsjechoslowaakse regering gaf haar ondersteuning en vanaf 1927 was het gebouwtje extraterritoriaal Joegoslavisch grondgebied. Omdat zowel Joegoslavië als Tsjechoslowakije in de jaren negentig ophielden te bestaan, was onduidelijk wie de eigenaar van het monument is. $\mathrm{Na}$ jarenlange verwaarlozing wordt het tempeltje nu eindelijk gerenoveerd.

1 Dit artikel is geschreven op basis van onderzoek gedaan binnen het project IGA_FF 2017:012, Středověké nizozemské divadlo van de Faculteit Letteren van de Univerzita Palackého te Olomouc. Mijn dank gaat ook uit naar Jelica Novaković-Lopušina voor inlichtingen over verschillende Joegoslavische gegevens en correcties op onjuistheden die hieromtrent in Olomouc genoteerd zijn. 


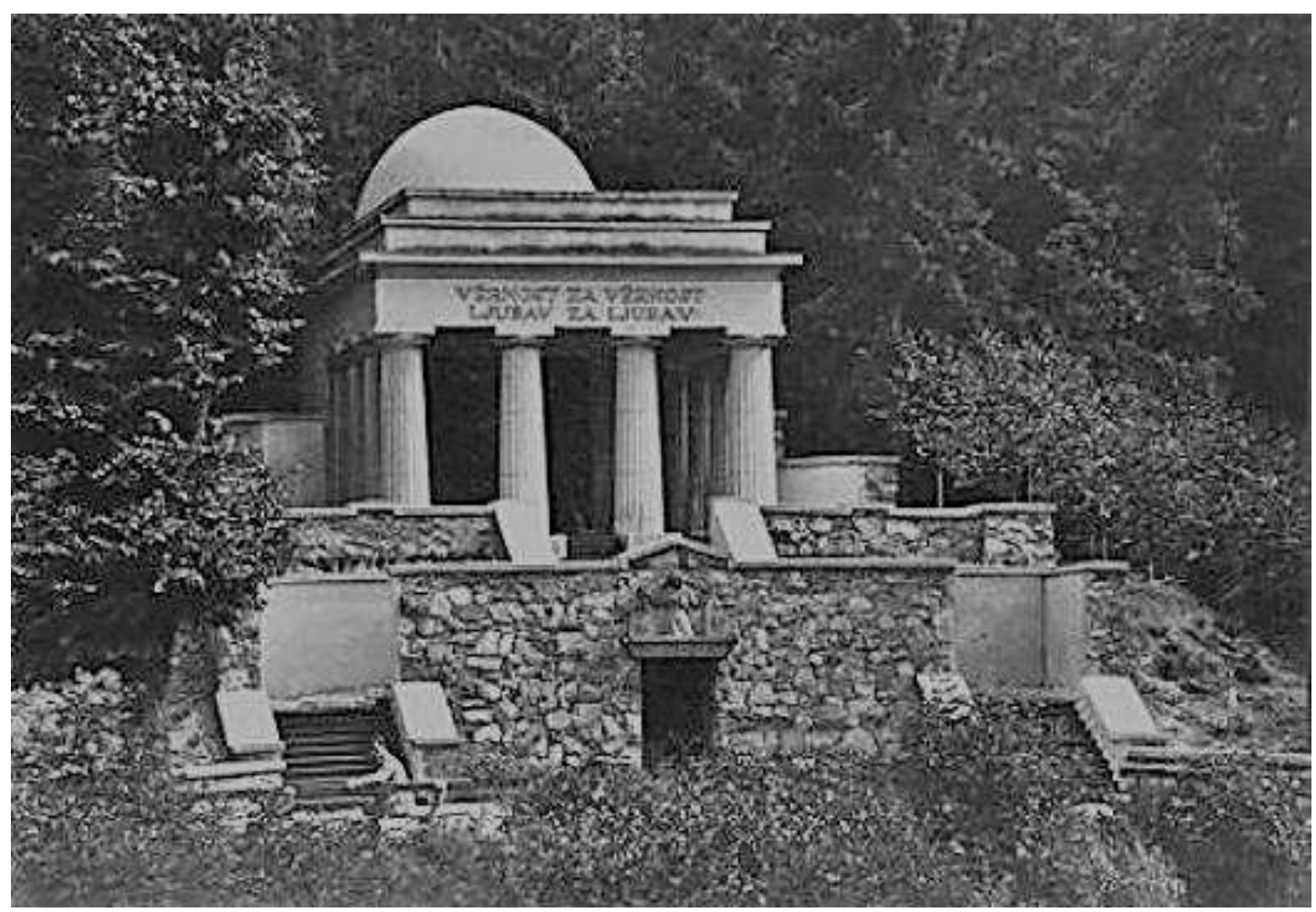

[Afb. 1. Joegoslavisch mausoleum te Olomouc, prentbriefkaart 1936.]

Het lot van het tempeltje is vergelijkbaar met dat van een andere "Joegoslavische immigrant" die als jongeman een van de initiatiefnemers voor dit monument was Otto František Babler (1901-1984). Babler was een van de meest veelzijdige Tsjechische vertalers van poëzie uit de twintigste eeuw. Hij liet ruim 4000 vertalingen uit en in een twintigtal talen na, maar zijn werk kon na 1948 vaak niet worden uitgegeven, omdat het niet strookte met de officiële politieke richting. Daardoor was het alleen bij enkele insiders bekend. De laatste jaren is er dankzij toenemende interesse voor katholiek georiënteerde Tsjechische literatuur en ook voor Tsjechische banden met de Balkan meer aandacht voor zijn werk gekomen. In deze kleine studie wordt zijn rol voor de introductie van Joegoslavische en Nederlandstalige literatuur met spirituele thematiek belicht.

\section{Bosnië-Hercegovina}

$\mathrm{Na}$ de bevrijding van de Turkse overheersing in 1878 werd Bosnië en Hercegovina in 1908 officieel door de Oostenrijkse monarchie ingelijfd, een act die mede aanleiding was voor de Eerste Wereldoorlog. Dankzij de Oostenrijkse bemoeienissen kwamen er vele ambtenaren, ingenieurs en militairen naar het nieuwe rijksdeel. Een van hen was de uit Karinthië afkomstige mijnbouwer Otto Babler (1872-1901) die werk vond in de staatsmijnen van Zenica. Babler was afkomstig uit een nationaal gemengde familie - zijn vader, woudopzichter, was Duitstalig, zijn moeder was van Sloveense afkomst. Babler maakte kennis met zijn latere vrouw Jindřiška Jandová (1876-1958) toen zij in 1894 op bezoek was bij haar twee zussen die beiden met hun echtgenoten naar Bosnië waren verhuisd. Zij kwam uit een onderwijzersfamilie in het plaatsje Slany nabij Praag, waar het huwelijk in 1895 plaats vond. Op 26 januari 1901 werd hun enige kind, Otto Karlo Franjo Babler geboren. Kort daarna stierf Otto Babler sr. op 13 september 1901 als gevolg van een darmaandoening in de trein op weg naar het Landsziekenhuis in 
Sarajevo, waar hij voor deze kwaal behandeld had moeten worden. ${ }^{2}$

Otto František, zoals hij zich later steevast schreef, groeide in een drietalige omgeving op en leerde van jongs af aan Servokroatisch, Duits en Tsjechisch. Na de dood van haar man was zijn moeder ingetrokken bij haar zuster Josefa, getrouwd met Ignác Letocha, ambtenaar van het kadaster in Prijedor die tevens als voogd van het jongetje fungeerde. Daar maakte Otto op de lagere school kennis met beide versies van het Servokroatisch - de éne helft van de klas schreef de taal in Cyrillisch schrift, de andere helft in Latijns schrift - naar keuze van de ouders. Otto leerde beide versies. Toen Letocha in 1910 promotie maakte naar het landskadaster in de hoofdstad Sarajevo, verhuisden Otto en zijn moeder mee. Otto bezocht daar de beste school van de stad, de Real-Schule Franz Josef I. Op deze school ontwikkelde hij zijn talent voor talen, een talent dat hij in de destijds veeltalige stad ook ten volle kon benutten.

Hoewel de jonge Otto als scholier op de noodlottige 28 juni 1914 eigenlijk in de rijen scholieren had moeten staan die aartshertog Frans-Ferdinand en zijn vrouw in Sarajevo verwelkomden, had hij de voorkeur gegeven aan een boek dat hij net las en was ergens in een hoekje gaan zitten lezen. Zo hoorde hij pas 's avonds wat er was gebeurd. Na het uitbarsten van de wereldoorlog werd de bevolking van Sarajevo geëvacueerd. Otto's moeder besloot in juli 1914 om tijdelijk samen met haar zwager naar Moravië te gaan. Omdat haar zwager als gevolg van een oogkwaal blind werd, verzocht deze om voortijdige pensionering en bleef de familie in Olomouc wonen.

\section{Begin van de vertaalcarrière}

De spanningen tussen de Duitstalige en Tsjechischtalige bevolking van Olomouc waren voor de jonge Otto die aan het relatief vreedzame etnische samenleven in Bosnië gewend was, eerst een shock. Al snel besloot hij om zich van twisten afzijdig te houden. Hoewel zijn moeder hem bij de Deutsche Realschule inschreef, had hij ook met Tsjechischtalige leeftijdsgenoten veel contact. Zijn Duitsleraar Heinrich Suchanek was voor hem een steun en voorbeeld die in veel opzichten de gestorven vader verving. Op het gymnasium breidde Otto zijn talenkennis nog met Frans uit, later leerde hij nog Engels, Italiaans, Pools en Russisch. Op school raakte hij bevriend met Rudolf Michalik (1901-1993), later schilder en antroposoof. Typisch voor de levenshouding van Otto Babler is dat hij met beiden contact bleef houden ook nadat zij in 1945 als Duitstaligen Tsjechoslowakije uitgezet waren.

In zijn schooltijd begon Otto met zijn eerste pogingen als vertaler, vooral Tsjechisch-Duits en Duits-Tsjechisch, maar daarnaast begon hij in 1916 ook met het vertalen van Dantes $\mathrm{Hel}$ in het Tsjechisch - later zou hij de hele Divina Commedia vertalen, wat tevens zijn bekendste vertaling is. Na zijn eindexamen in 1919 besloot hij om van literair vertalen zijn beroep te maken. Hij vertaalde vooral poëzie, zowel voor Tsjechischtalige kranten als Nasinec (Ons Vaderland) en Československý deník

2 De biografische gegevens over Otto F. Babler berusten op Hrdinová 2003, 2003b en 2008, Rokyta 1984,

Stavinohová 1984 en Storek 1985. 


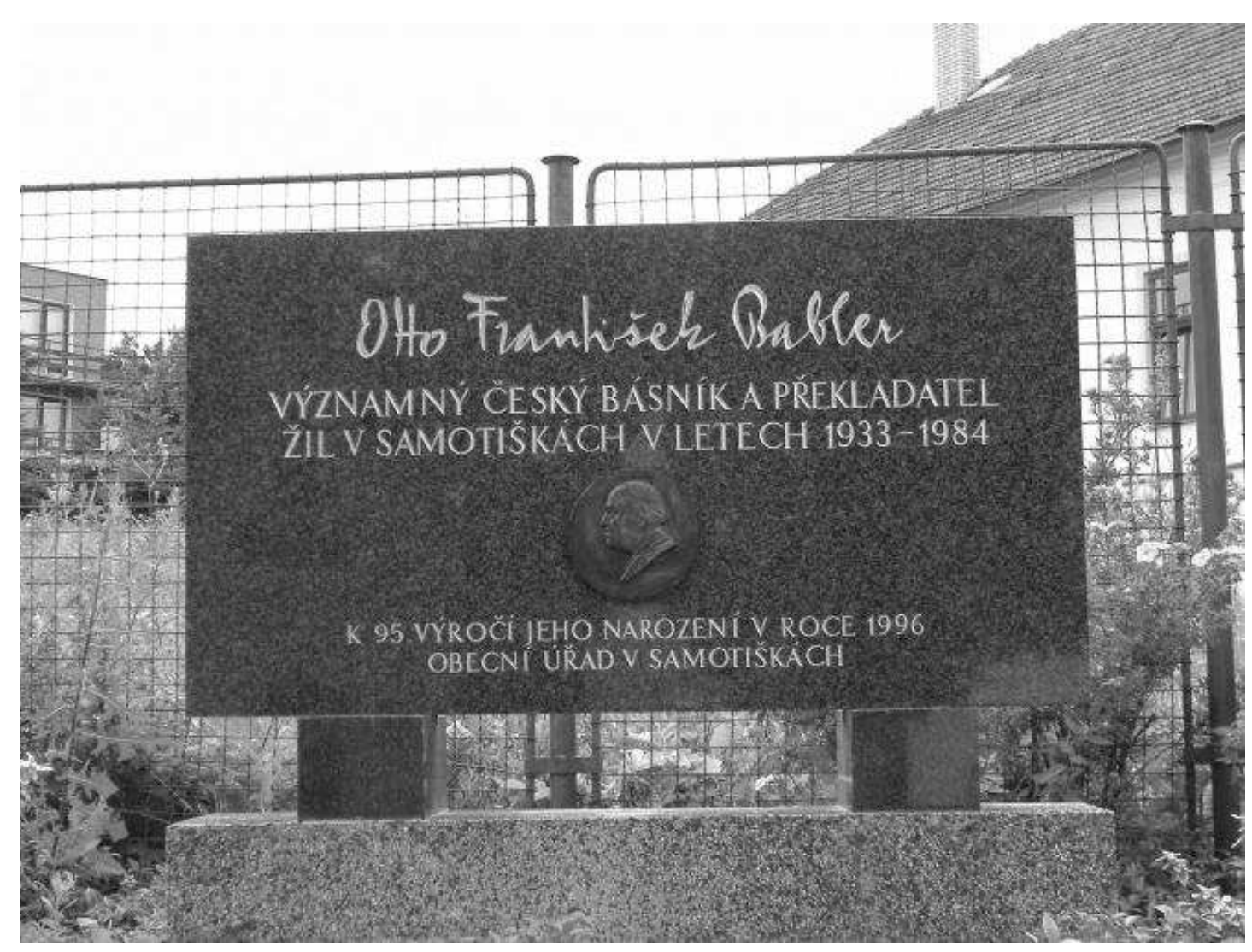

[Afb. 2. Herdenkingsplaat voor Otto Babler van de gemeente Samotisky. Bron: https://www.mistopisy.cz/pruvodce/obec/8440/samotisky/.]

(Tsjechoslowaaks Dagblad) als voor de Duitstalige Prager Presse en Hochland. Babler had contact met verschillende kringen intellectuelen - zowel met de streng katholieke groep rond Josef Florian (1873-1941) in Stará Ríše, als met de kring rond de progressiefliberale Joodse architect Paul Engelmann (1891-1965) bij wie hij kennis maakte met de linkse filosoof Josef L. Fischer (1894-1973) en met avantgarde schrijvers als Konstantin Biebl (1898-1951).

$\mathrm{Na}$ het uiteenvallen van Oostenrijk-Hongarije werd Otto op 28 oktober 1918 in de voorlaatste klas van de middelbare school automatisch Joegoslaviër en moest als zodanig zijn militaire dienstplicht in 1923-1924 in die staat vervullen, eerst in Ljubljana, daarna in de hoofdstad Belgrado. De hernieuwde kennismaking met zijn geboorteland versterkte de al in de jongeman aanwezige wens om als literair vertaler te leven.

\section{Uitgever en bibliofiel}

Na terugkeer uit Joegoslavië begon Babler eerst voor vrienden, later ook voor de verkoop bibliofiele edities van zijn vertalingen in beperkte aantallen uit te geven. De gemiddelde oplage was 150 stuks. Dankzij zijn vele vertalingen voor tijdschriften had hij contact met tal van belangrijke illustrators, één van hen was de reeds genoemde Rudolf Michalik. Hij groepeerde de vertalingen in series, de belangrijkste van deze was Hlasy (Stemmen), in welke serie tussen 1926 en 1947 in totaal 48 titels uitkwamen. In de eerste jaren gaf Babler vooral thematisch gegroepeerde anthologieën uit, na 1934 richtte hij zich op afzonderlijke auteurs. 
In 1928 trouwde hij met Marie Mejsnarová (1896-1987). ${ }^{3} \mathrm{Na}$ de geboorte van hun zoon Otto in 1930 liet Babler in 1933 in het dorpje Samotisky op de heuvel Svatý Kopeček (Heilige Berg) ten noorden van Olomouc een huis bouwen, waar hij tot zijn dood bleef wonen.

Zijn uitgeverijtje was in het atelier van dit huis gevestigd. In 1936 kreeg Babler het Tsjechoslowaakse staatsburgerschap en werd prompt opnieuw voor militaire dienst opgeroepen, omdat zijn Joegoslavische diensttijd niet werd erkend. Zijn slechte gezichtsvermogen redde hem - hij werd afgekeurd en nam een baan aan als bibliothecaris van de Kamer van Koophandel van Olomouc.

Tijdens de oorlogsjaren moest Babler zijn uitgeverswerk staken. Veel Joodse vrienden werden weggevoerd en kwamen nooit meer uit de concentratiekampen terug, na de oorlog verloor hij ook een deel van zijn niet-Joodse Duitstalige vrienden toen de Duitstalige bevolking uit Tsjechoslowakije werd verdreven - al wist hij met sommigen in contact te blijven.

\section{Bibliothecaris en literair vertaler}

In 1946 was de uit Nederlandse ballingschap teruggekeerde filosoof Josef L. Fischer rector van de hernieuwde universiteit van Olomouc geworden. Op verzoek van Fischer werd Babler lector Servokroatisch. Deze baan betekende bestaanszekerheid, vooral na de communistische machtsovername van 1948, toen de kamer van koophandel ophield te bestaan. Voor de overtuigde katholiek die Babler was, betekende de machtsovername een tragedie, vooral toen een paar jaar later de vervolging van katholieke intellectuelen begon. Velen van zijn vrienden werden het slachtoffer. Babler moest zijn uitgeversactiviteiten opnieuw staken, maar bleef verder buiten schot waarschijnlijk werd hij gered door zijn weigering om zich bij een bepaalde groep aan te sluiten en door het feit dat hij tijdens de oorlog met zijn vrouw ontsnapte Russische krijgsgevangenen bij hen thuis had laten onderduiken. Fischer zorgde ervoor dat de toenmalige universiteitsbibliotheek Babler aanstelde. Babler bleef als assistent in de bibliotheek en als lector Servokroatisch bij de letterenfaculteit werken tot hij in 1956 met invaliditeitspensioen ging, omdat hij aan één oog blind werd.

Dat in 1952, midden in de Stalinistische era, zijn vertaling van Dantes Divina Commedia niet alleen werd uitgegeven maar ook positieve besprekingen in de toenmalige pers kreeg, moet hij als een soort satisfactie hebben gevoeld. Hoewel Babler deelnam aan de conferentie over Kafka bij de Academie van Wetenschappen in 1963 die de feitelijke start van de Praagse Lente was en in de periode 1963-1968 opnieuw vertalingen van katholieke Tsjechische dichters maakte die in de jaren vijftig vervolgd waren, werd hij bij de represailles na 1969 opnieuw niet gestraft. Hierbij speelde waarschijnlijk zijn leeftijd en het feit dat hij nimmer politiek engagement had getoond een rol. In zijn laatste levensjaren wijdde Babler zich vooral aan het vertalen en uitgeven van middeleeuws Franse romans als de Roman de Renart in het Tsjechisch.

3 Gegevens Kubásková 1994:10. 
In 1983 werd hij ook aan zijn tweede oog blind. Op 24 februari 1984 stierf hij in familiekring en na ontvangst van de laatste sacramenten.

\section{Spiritueel-katholieke oriëntatie}

Babler was een gelovige katholiek. Evenals hij weigerde om te kiezen tussen de verschillende literaire groepen, bleek hij in staat om bevriend te zijn met de meest uiteenlopende groepen katholieken die vaak met elkaar absoluut niet overweg konden. In Moravië waren er drie katholieke groepen die ook literair bezig waren. De Dominicanen in Olomouc gaven onder leiding van hun abt Silvestr Braito (18981962) theologische literatuur uit. ${ }^{4}$ Babler was persoonlijk met Braito bevriend, maar was niet geïnteresseerd in het vertalen van heiligenlevens of theologische tractaten. Wel gaf hij vaak vertalingen van gedichten en korte verhalen uit allerlei talen uit in katholieke dagbladen als Našinec [Ons Vaderland], de belangrijkste katholieke krant van die tijd, Selské noviny [Boerenkrant], de partijkrant van de Agrarische partij, en Moravská domovina [Het Moravische thuis] van de met deze partij gelieerde Bond van tuinbouwers en keuterboeren. ${ }^{5}$ Hij werkte ook als vertaler samen met de beide belangrijkste katholieke uitgeverijen van het interbellum - Akord in Brno en Vyšehrad in Praag.

De Katolická moderna, de modernistengroep rond de priester Karel DostálLutinov (1871-1923) was opgekomen onder het pontificaat van de hervormingsgezinde paus Leo XIII in de jaren negentig van de negentiende eeuw, maar was onder diens conservatieve opvolger Pius $\mathrm{X}$ in het diskrediet geraakt. Zij probeerden enerzijds om de katholieke kerk dichter bij de gelovigen te brengen - bijvoorbeeld door te pleiten voor kerkdiensten in de volkstaal - en waren anderzijds literair actief om een katholiek antwoord te geven op de merendeels niet- of zelfs antikerkelijk georiënteerde Tsjechische literatuur van eind negentiende eeuw. De groep gaf het tijdschrift Nový život [Het nieuwe leven] uit. Toen de beweging feitelijk door de kerkleiding verboden werd, werd het tijdschrift in 1907 opgeheven. In 1912 begon Dostál-Lutinov met een nieuw tijdschrift Archa [De ark] dat zich meer op katholieke literatuur richtte en tot het verbod door de communistische regering in 1948 bleef bestaan. Het tijdschrift bouwde een belangrijke naam vooral voor vertalingen van poëzie op.

De laatste groep betreft de Tsjechische tak van de Renouveau catholique, een Franse conservatieve katholieke hervormingsbeweging die zeer op de Mariaverering gericht was, maar tegelijkertijd ook kritisch was jegens de hoge clerus. De leiding van deze tak berustte bij de onderwijzer Josef Florian (1873-1941) die in zijn woonplaats Stará Ř́šse een uitgeverijtje had dat vooral bibliofiele uitgaven, zogeheten cimélie afgeleid van het Latijnse woord cimelia dat een mooi geillumineerd handschrift of een mooi versierde wiegendruk aanduidt, produceerde. Deze zeer spiritueel georiënteerde

4 De Dominicanen gaven in hun editie Krystal o.a. verschillende werken van Ruusbroec uit.

5 Officiële benamingen Republikánská strana zemědělského a malorolnického lidu en Zemské sdružení domkářů a malorolníků na Moravě. 
groep had ondanks het tamelijk sectarische karakter sterke aantrekkingskracht voor met name symbolistische dichters. Dat gold ook voor de Renouveau Catholique bekende dichters en schrijvers die zich bij de stroming aansloten waren bijvoorbeeld Karl-Joris Huysmans (1848-1907), T.S. Elliot (1888-1965) of in Nederland Pieter van der Meer de Walcheren (1880-1970). We treffen dan ook in Florians omgeving verschillende belangrijke Tsjechische katholieke dichters aan als Otokar Březina (18681929), Jaroslav Durych (1886-1962), Jakub Deml (1878-1961), en Jan Zahradníček (1905-1960). Met de laatste twee zou Babler goed bevriend raken.

\section{Jakub Deml}

Eén van de reeds genoemde illustrators die Bablers bibliofiele uitgaven illustreerden was Josef Váchal (1884-1969). Deze was ook als symbolistisch dichter actief. Na een tijdje in de kringen van de katholieke modernen, was hij rond 1910 in de groep van Josef Florian terecht gekomen. Door zijn ervaringen aan het Italiaanse front aan het einde van de Eerste Wereldoorlog keerde hij zich uiteindelijk van de katholieke kerk af en werd na de dood van zijn vrouw in 1922 occultist. Via Váchal maakte Babler kennis met Jakub Deml (1878-1961). Deml was in 1902 tot priester gewijd en was zoals veel van zijn vrienden van het seminarie in Brno een aanhanger van de modernistenbeweging in de katholieke kerk geworden. In 1905 maakte Deml kennis met Florian en kwam onder invloed van diens groep.

Deml werd in 1907 officieel om gezondheidsredenen van zijn priesterlijke verplichtingen ontheven en wijdde zich nadien volledig aan de literatuur. In de kringen van de Renouveau Catholique waren mirakellegenden, middeleeuwse auteurs van visioenen en romans die zich afspeelden op het 'zuiver gebleven' katholieke platteland populair. Deml maakte in 1915 op verzoek van Florian een mooie Tsjechische bloemlezing van het werk van de Nederlandse mysticus Jan van Ruusbroec (12931381). Deze was in 1908 zalig verklaard en zodoende internationaal onder de aandacht gebracht. In 1918 ontmoette Deml de schrijfster en uitgeefster Pavla Kytlicová (1874-1932) die zijn mecenas werd en tot haar dood met hem zou samenleven. De eigenzinnige Deml had meermalen problemen met de hogere clerus. Deze problemen en zijn intieme vriendschappen met verschillende vrouwen leidden ertoe dat hij zijn priesterschap wisselend kon uitoefenen of juist moest neerleggen. Zelf bleef hij zich tot zijn dood toe als priester zien.

Deml woonde sinds 1922 in het Zuid-Moravische plaatsje Tasov, waar hij met ondersteuning van o.a. president Masaryk door de functionalistische architect Bohuslav Fuchs (1895-1972) een villa had laten bouwen. Hij woonde daar met Kytlicová. Babler raakte nauw met Deml bevriend, zozeer zelfs dat zijn huwelijk in Demls woonplaats werd afgesloten en niet in de woonplaats van de bruid, zoals gebruikelijk was. ${ }^{6}$ Deml was tevens de priester die de plechtigheid celebreerde. Een klein, maar significant detail is dat Deml zijn villa Bosna, Bosnië, noemde, naar het geboorteland van Babler.

6 Marie Mejsnarová was afkomstig uit Dvůr Králové en woonde in Olomouc. 


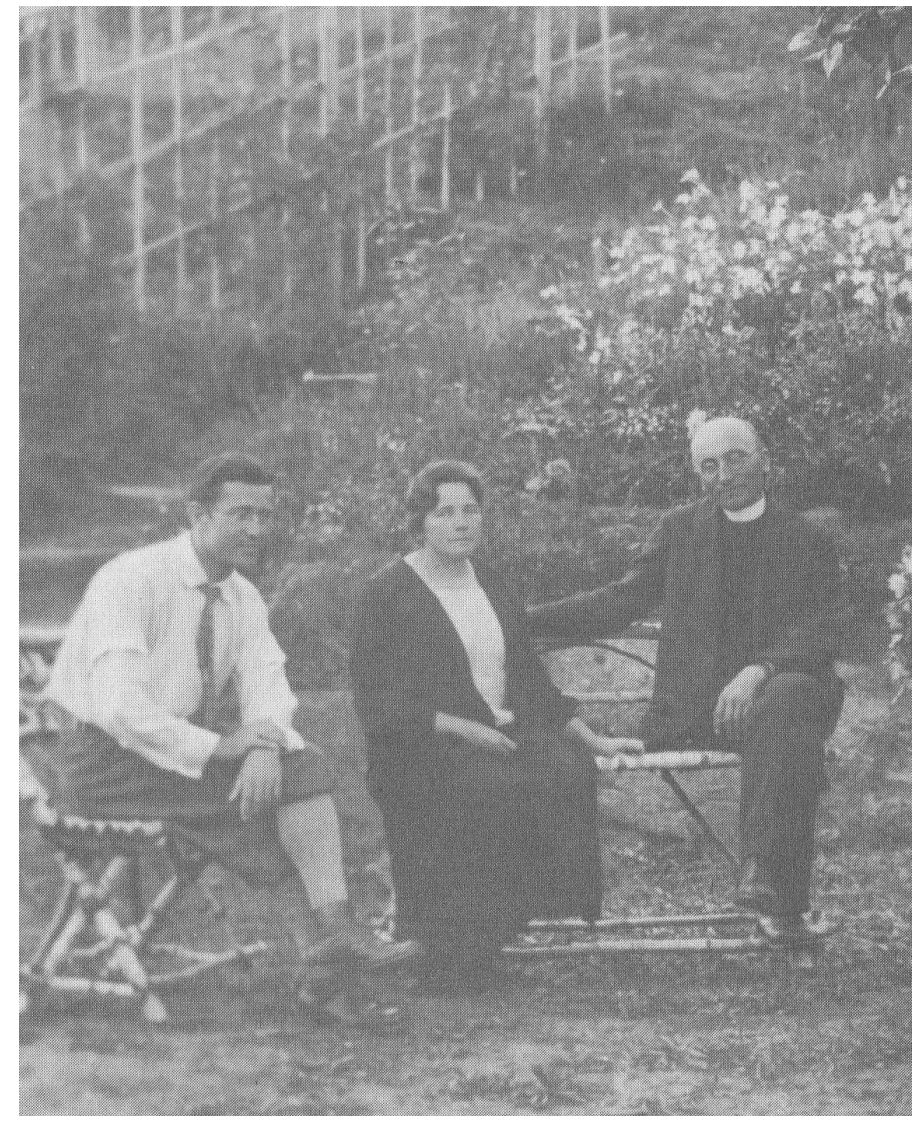

[Afb. 3. Otto F. Babler, Pavla Kytlicová en Jakub Deml te Tasov, 1928. Bron: Hrdinova 2008:113.]

\section{Vertalingen uit Zuidslavische talen}

Babler vertaalde vooral gedichten en prosa vanuit Zuidslavische talen in het Tsjechisch. De honderden teksten die hij vertaalde, lopen qua genre zeer uiteen, van gedichten en prosa tot drama. Zijn bekendste vertalingen zijn de ballade Judit (1937) van katholieke Bosnische aartsbisschop Ivan Evanđelista Šarić (1871-1960), Vox clamans - Dantův výkř́k [De klagende stem - de kreet van Dante] uit 1946 van de Kroatische dichter Ivo Vojnović (1857-1929), Travnická kronika [De kroniek van Travmik] uit 1958 van de Joegoslavische schrijver Ivo Andrić (1892-1975), Můj malý žaltár [Mijn kleine psalmboek] van de Kroatische dominicaan Rajmund Kupareo (1914-1996) en een antologie Zrnko dojetí [Een vlaag van emotie] van de Kroatische dichteres Vesna Parun (1922-2010) uit 1976.

Uit het Servisch en het Sloveens vertaalde Babler vooral volksballaden en -legenden. Verder stelde hij verschillende antologieën samen, waarin Zuidslavische dichters goed vertegenwoordigd waren. De opmerkelijkste vertaling uit deze groep talen is waarschijnlijk zijn vertaling van de Bosnische volksballade Hasanaginica (Babler 1926). Deze oude mondelinge ballade, de 'rouwzang van de edele echtgenote van de Hasan Aga' werd rond 1646 gedicht en in 1774 voor het eerst gedrukt door de Italiaanse volkskundige en reiziger Alberto Fortis (1741-1803) in diens Viaggio in Dalmazia. In 1933 gaf Babler ook een Duitse vertaling van de ballade uit (Babler 1933b). ${ }^{7}$

Het zal duidelijk zijn dat de vertalingen uit Zuidslavische talen aansluiten bij de spiritueel-katholieke oriëntatie van Babler. Deze oriëntatie speelde ook een rol bij zijn vertalingen uit het Nederlands.

7 De eerste Duitse vertaling was overigens door niemand minder dan Goethe gemaakt. 


\section{Vertalingen uit het Nederlands}

Het aantal bekende vertalingen uit het Nederlands van Babler is beperkt. De meeste bewaard gebleven vertalingen zijn uit zijn beginperiode. De reden daarvan is Bablers oriëntatie op spirituele literatuur die ook in zijn vertalingen uit Zuidslavische talen zichtbaar is. Bovendien had Babler, anders dan de twee belangrijkste vertalers uit het Interbellum - Lída Faltová (1890-1944) en Rudolf J. Vonka (1877-1964) - geen rechtstreekse banden met de Lage Landen. Helaas voor de Tsjechische lezer, het is een interessante gedachtenoefening hoe bijvoorbeeld gedichten van Martinus Nijhoff in Bablers Tsjechisch zouden hebben geklonken.

De meeste vertalingen uit het Nederlands behoorden tot de allereerste die Babler heeft gemaakt, in de periode 1920-1922, tussen zijn eindexamen en zijn dienstplicht. Eén vertaling dateert van 1927, uit de periode toen Babler begon met de uitgave van zijn serie Hlasy. Het gaat om een opmerkelijk stel teksten: uit 1922 dateren een vertaling van de Beatrijs-legende en twee novelles van Felix Timmermans: fragmenten uit diens bekendste werk Pallieter en het werkje De Zeer Schone Uren van Juffrouw Symforosa, Begijntjen uit 1918. De latere tekst is een kerstgedicht van de contrareformatorische dichter Johannes Stalpaert van der Wiele (1579-1630). In alle drie gevallen stelde Babler in zijn colofon de werkjes uit het Oud-Hollands - Beatrijs - respectievelijk het Vlaams vertaald te hebben. Met name in de vertalingen van Timmermans' werk is zichtbaar dat Babler het Vlaams niet altijd volledig begrepen heeft en kennelijk de Duitse vertalingen van Insel-Verlag niet bij de hand had. Overigens stelde Babler dat zijn vertalingen van Timmermans' novelles geautoriseerd waren. $^{8}$

Vermoedelijk zette Deml Babler op het spoor van de Beatrijs-legende. Deze legende paste in het genoemde programma van de Renouveau Catholique: het was een mirakellegende waarin de Heilige Maagd de hoofdrol speelde (en de hogere clerus juist niet). Volgens eigen vermelding vertaalde Babler de door C.G.N. de Vooys in 1903 uitgegeven prozalegende. Ook de interesse voor Timmermans had vermoedelijk haar oorsprong in de groep rond Florian, want in de door Florian uitgegeven serie Nova et vetera mystiky [Oude en nieuwe zaken van de mystiek] was in 1920 een fragment van Timmermans' Het Kindeke Jezus in Vlaanderen verschenen in een vertaling van de hand van pater Ludvík Vrána (1883-1969), een vriend van Deml. ${ }^{9}$

Maar Babler gaf voor zijn eerste Nederlandse vertalingen de voorkeur aan het modernisten-tijdschrift Archa en de kranten Selské noviny en Moravská domovina. Eén fragment uit Pallieter, Een Meiavond, komt alleen in Selské listy voor (Timmermans 1922b).$^{10}$ Het fragment Het vogelenbezoek uit Pallieter van Timmermans werd vrijwel gelijktijdig in de beide genoemde dagbladen uitgegeven (Timmermans 1922c, 1922d).

8 Het is nog niet mogelijk geweest om deze bewering op juistheid te controleren.

9 Vrána werd evenals Deml vanwege zijn contacten met de groep van Florian gesuspendeerd. Uiteindelijk koos hij er maar voor om - onder dreiging van excommunicatie - in 1929 te gehoorzamen en alle contacten mer Florian af te breken.

10 Het werd een paar jaar later ongewijzigd in Našinec herdrukt (Timmermans 1925). 
Krásné čtení

o panně Symforose

OLOMOUC

1929
[Afb. 4. Titelpagina Krásné čtení panně Symforose, Olomouc 1929. Exemplaar auteur.]

Babler had de gewoonte om vertalingen die hijzelf geslaagd vond, later nogmaals te redigeren en als bibliofiele druk in eigen beheer uit te geven. In zo'n geval gaf hij in de uitgave precies aan, welk origineel hij had gebruikt. Dit is het geval met zowel de Beatrijs-legende als met Juffrouw Symforosa.

In het exemplaar van het tijdschrift Archa in de wetenschappelijke bibliotheek van Olomouc zijn in de Beatrijs-tekst met de hand verschillende kleine verbeteringen genoteerd die later door Babler in zijn bibliofiele uitgave zijn uitgevoerd. In alle gevallen is de tekst door Babler wat meer gestroomlijnd.

Voor de vertaling van het gedicht van Stalpaert van der Wiele is op dit moment alleen de bibliofiele uitgave bekend, zowel uitgegeven in het boekje Strom ze srdce [Een boom uit het hart], het zesde deeltje van de serie Hlasy (1927), als apart als eerste gedicht van een kerstboekje Vánoční knižka (1935) in een mooiere uitgave. Er is tussen deze twee versies geen verschil in de vertaalde tekst.

Opmerkelijk is dat Babler geen bibliofiele versie heeft gemaakt van zijn Pallieter-vertaling. De reden daarvan is waarschijnlijk dat de vrijzinnige protestant en vrijmetselaar Vonka in 1927 een eigen vertaling van Pallieter had gemaakt die was uitgegeven bij het grote, sociaal-democratische huis Družstevní práce [Collectieve Arbeid] (Timmermans 1927).

Naast de genoemde Tsjechische vertalingen is er één vertaling uit het Nederlands in het Duits bekend van Babler. Deze betreft het gedicht Het schrijverke van Guido Gezelle, uitgegeven in Bablers bloemlezing van diergedichten Kreis der Tiere (Babler 1939). Opmerkelijk is dat dit gedicht, anders dan de meeste andere in de bloemlezing, niet eerder door hem in het Tsjechisch werd vertaald.

\section{Karakter van de vertalingen}

Literaire vertalingen zijn sinds de herleving van de Tsjechische literatuur eind achttiende eeuw een inherent deel van deze literatuur. De meningen over hoe een literair vertaler tewerk moet gaan, maakten in deze twee eeuwen vrij grote veranderingen door. Waar begin negentiende eeuw de nadruk werd gelegd op het zoveel mogelijk aanpassen van de tekst aan de Tsjechische lezer, overheerste in de tweede helft van die eeuw het idee 
dat de tekst juist zo correct mogelijk de taal en inhoud van de originele tekst moest volgen. In deze periode kwam ook het idee op dat vertalingen steeds rechtstreeks uit de brontaal naar de doeltaal moeten worden gemaakt.

In de jaren twintig van de twintigste eeuw formuleerden de theoretici van de Praagse School een vertaaltheorie, zij kwamen die met de idee van een 'taalsleutel'. Naar hun idee moet een vertaling vooral de inhoud correct weergeven, zonder noodzakelijkerwijze de vorm op de voet te volgen. Zo vormde bijvoorbeeld de Praagse hoogleraar germanistiek, theatercriticus en vertaler Otokar Fischer (1883-1938) een school die deze ideëen verspreidde. Babler beschouwde Fischer die o.a. het abele spel Lanseloet van Denemerken en de roman De wandelende Jood van August Vermeylen vertaalde, als zijn voorbeeld.

Babler legde de nadruk op christelijke spiritualiteit, volksmystiek en intieme lyriek. Vrouwen, vooral in de rol van beschermende of liefhebbende moeder, spelen een grote rol in door Babler vertaalde poëzie - het gedicht van Stalpaert van der Wiele, waarin de armoedige situatie van het kindje Jezus op een liefdevolle wijze door zijn moeder wordt beschreven, is een goed voorbeeld. De literair theoreticus Oldřich Králík (1907-1975) omschreef Bablers vertaaloeuvre als 'cherubijns' (Hrdinová 2008:51).

\section{Conclusie}

Hoewel de naam van Otto F. Babler vooral verbonden is met vertalingen uit Zuidslavische talen en uit het Tsjechisch naar het Duits, heeft hij enkele mooie vertalingen uit het Nederlands gemaakt. Deze vertalingen sluiten inhoudelijk aan op zijn spiritueel-katholieke oriëntatie. Bablers vertalingen uit het Nederlands zijn niet groot in aantal, maar brachten Nederlandstalige literatuur onder de aandacht van literair georiënteerd publiek. Bovendien is hij interessant als een typische exponent van een Centraal-Europese literair vertaler met een multiculturele achtergrond die dankzij zijn kennis van verschillende culturen een vertolker van zowel de Germaanse als verschillende Slavische culturen was en deze met elkaar in contact bracht.

\section{Literatuuropgave}

Babler, Otto F. 1922. 'Sestra Beatrice. Brabantskílegenda.' Archa. Měsičník pro literaturu, umění, kulturu a život 10, pp. 282-285. Vertaling Otto F. Babler. Origineel: Van een nonne die Beatriis hiete. In: (ed.) C. G. N. De Vooys, Middelnederlandse Marialegenden 1. Onser liever vrouwen miraculen. Naar het Katwijkse handschrift. Leiden: Brill, 1903, pp. 42-51.

Babler, Otto F. 1926. Hasanaginica. Olomouc: Babler. 
Babler, Otto F. 1933. Sestra Beatrice. Brabantská legenda. Svatý Kopeček: Babler (Heliotrop 1). Vertaling Otto F. Babler. Origineel: Van een nonne die Beatriis hiete. In: (ed.) C. G. N. De Vooys, Middelnederlandse Marialegenden 1. Onser liever vrouwen miraculen. Naar het Katwijkse handschrift. Leiden: Brill, 1903, pp. 42-51.

Babler, Otto F. 1933b. Hassan-Agas Gattin: südslawisches Volkslied. Heiliger Berg bei Olmütz: Otto F. Babler (Heliotrop 2).

Gezelle, Guido. 1939. 'Schreiberchen'. In (ed.) Otto F. Babler, Kreis der Tiere. Eine Anthologie von Tiergedichten. Hamburg: Dr. Ernst Hauswedell, pp. 18-20.

Kupraeo, Rajmund. 2009. Můj malý žaltář. S.1., s.n. (Olomouc). Vertaler Otto F. Babler. Origineel Blagoslov zvijezda (1961).

Parun, Vesna. 1976. Zrnko dojití. Blansko: Závodní klub ROH ČKD Blansko. Vertaling Otto F. Babler.

Stalpert van der Wiele, Johannes. 1927. 'Maria laská novorožeňátko.' In: (ed.) Otto F. Babler, Strom ze srdce. Písně o Kristu. Olomouc: Lidové závody tiskařské, pp. 19-20 (Hlasy VI). Vertaling Otto F. Babler. Origineel: Smeeck-woorden Mariae, tot den nieu-geboren. Uit: (ed.) Albert Verwey, De honderd beste gedichten in de nederlandsche taal. Amsterdam: Kirberg en Kesper, 1915. ${ }^{11}$

Stalpert van der Wiele, Johannes. 1935. 'Maria laská novorožeňátko.' In: (ed.) Otto F. Babler, Vánoční knižka. Nový Jičín: Kryl \& Scotti. Niet gepagineerd. Vertaling Otto F. Babler. Origineel: Smeeck-woorden Mariae, tot den nieu-geboren. Uit: (ed.) Albert Verwey, De honderd beste gedichten in de nederlandsche taal. Amsterdam: Kirberg en Kesper, 1915.

Šarić, Ivan Evanđelista. 1937. Judit. Svatý Kopeček: Babler. (Hlasy 34).

Timmermans, Felix. 1922. 'Krásné čtení o panně Symforose.' In: Archa. Měsíčník pro literaturu, umění, kulturu a život 10, pp. 376-390. Vertaling Otto F. Babler. Origineel: De zeer schone uren van juffrouw Symforosa, begijntjen (1918).

Timmermans, Felix. 1922b. 'Májový večer. Kapitola z románu Pallieter.' Selské listy 40, nr. 22, p. 1 (22 mei 1922). Vertaling Otto F. Babler. Origineel Een Meiavond uit Pallieter (1916).

Timmermans, Felix. 1922c. 'Návstěva ptáků. Kapitola z románu Pallieter'. Moravská domovina 3, nr. 32, p. 3 (5 augustus 1922). Vertaling Otto F. Babler. Origineel: Het vogelenbezoek in Pallieter (1916).

Timmermans, Felix. 1922d. 'Návstěva ptáků. Kapitola z románu Pallieter.' Selské listy 10, nr. 22, p. 5 (22 mei 1922). Vertaling Otto F. Babler. Origineel: Het vogelenbezoek in Pallieter (1916).

Timmermans, Felix. 1925. 'Májový večer. Kapitola z románu Pallieter.' Našinec 61, nr. 102, p. 1 (7 mei 1925). Vertaling Otto F. Babler. Origineel Een Meiavond uit Pallieter (1916).

11 Originele uitgave in Gulde-jaers feest-daghen of den schat der geetselycke lof-sagen ghemaect op elcken feest dag van 't geheele iaer. Antwerpen: Ian Cnobbaert, pp. 1227-1228 (2 $\left.2^{\mathrm{e}} \mathrm{druk}\right)$. 
Timmermans, Felix. 1927. Pallieter. Praha: Družstevní práce. Vertaling Rudolf J. Vonka. Origineel Pallieter (1916).

Timmermans, Felix. 1929. Krásné čtení o panně Symforose. Olomouc: Lidové závody tiskařské. Vertaling Otto F. Babler. Origineel: De zeer schone uren van juffrouw Symforosa, begijntjen (1918).

\section{Secundaire literatuur}

Blahynka, Milan. 1985. 'Archa'. In: (ed.) Vladimír Forst, Lexikon české literatury. Osobnosti, díla, instituce. 1 A-G. Praha: Academia, pp. 80-81.

Džambo, Jozo. 2002. 'Zeničanin mnogih jezika.' Kalendar svetog Ante. Sarajevo: Svjetlo riječo, pp. 193-199.

Engelbrecht, Wilken. 2015. 'Vlaamse en Nederlandse literatuur door de ogen van Tsjechische katholieke vertalers gezien. In:_(ed.) Bas Hamers \& Muriel Waterlot, De Nederlanden met buitenlandse ogen. Lublin: Wydawnictwo KUL, pp. 19-39.

Hrdinová, Eva. 2003b. 'Otto František Babler - aneb o mostech mezi českou a německou literaturou.' In: (ed.) Milan Hrala, Český překlad 1945-2003. Praha: Univerzita Karlova, pp. 110-115.

Hrdinová, Eva. 2003b. 'O. F. Babler.' In: (ed.) Inge Fiala-Fürst \& Jörg Krappmann, Lexikon deutsch-mährischer Autoren. Olomouc: Univerzita Palackeho, pp. 1-7.

Hrdinová, Eva. 2008. Otto František Babler. Olomouc: Univerzita Palackého /Beiträge zur deutsch-mährischen Literatur 9).

Kubásková, Eva. 1994. Kdy zemřeli? Přehled českých spisovatelů a publicistů zemřelých v létech 1986-1990 s doplňky za predchozí léta. 1. A-J. Praha: Národní knihovna.

Rokyta, Hugo. 1984. 'In memoriam O. F. Bablers'. Adalbert-Stifter-Institut des landes Oberösterreich. Vierteljahresschrift 33, Folge 3-4, pp. 188-189.

Stavinohová, Zdeňka. z.j. (=1989). 'Překladatel Otto František Babler'. Acta Universitatis Carolinae - Philologica 2-3. Translatologica Pragensia III, 2. Praha: Univerizta karlova, pp. 251-257.

Storek, Břetislav. 1985. 'Babler, Otto František.' In: (ed.) Vladimír Forst, Lexikon české literatury. Osobnosti, díla, instituce. 1 A-G. Praha: Academia, pp. 106-108.

Archieffonds

Knihovna Otto F. Babler, Muzeum umění, Olomouc - zie http://www.olmuart.cz. 